\title{
TOMASZ SKRZYŃSKI
}

ORCID: 0000-0003-2063-4396

Uniwersytet Pedagogiczny im. Komisji Edukacji Narodowej w Krakowie

\section{Kierownik budowy pociągów pancernych i portów rzecznych oraz uczony - Kazimierz Franciszek Vetulani}

Stan badań nad losami inżyniera, teoretyka budownictwa i matematyka Kazimierza Franciszka Vetulaniego pozostawia wiele do życzenia. Najcenniejszym jest artykuł Lecha Maligrandy i Jarosława G. Prytuły poświęcony siedemnaściorgu uczonych lwowskich ${ }^{1}$. Niewiele wnoszą nieliczne krótkie notki biograficzne w języku polskim i ukraińskim² ${ }^{2}$. Pominięto Vetulaniego między innymi w Stowniku biograficznym matematyków polskich ${ }^{3}$, w obszernym studium historycznym o matematykach polskich w dwudziestoleciu międzywojennym ${ }^{4} \mathrm{i}$ w syntetycznych Uwagach o historii dwóch wieków mechaniki $w$ Polsce ${ }^{5}$.

Podstawą niniejszego tekstu są materiały przechowywane w: Archiwum Akt Nowych, Archiwum Akademii Górniczo-Hutniczej, Archiwum Nauki

1 L. Maligranda, J.G. Prytuła, Lwowscy uczeni wymienieni w przestuchaniach Banacha w 1944 r., „Wiadomości Matematyczne” 2013, nr 49 (1), s. 53-58.

2 M. Walczak, Ludzie nauki i nauczyciele podczas II wojny światowej. Ksiega strat osobowych, Warszawa 1995, s. 150; Z. Popławski, Wykaz pracowników naukowych Politechniki Lwowskiej w latach 1844-1945, Kraków 1994, s. 196. O istnieniu notki biograficznej Vetulaniego w języku ukraińskim: L'vìv 'ka politehnika v publikaciàh (1844-2013) bibliografičnij pokažčik, red. Ì. Bêlous, O. Šiški, L'vìv 2014, s. 542. Popularnonaukowej książki, w której ta notka biograficzna jest zamieszczona, nie udało się odnaleźć w polskich bibliotekach.

3 Stownik biograficzny matematyków polskich, red. S. Domaradzki, Z. Pawlikowska-Brożek, D. Węglowska, Tarnobrzeg 2003, s. 251-252.

4 M. Przeniosło, Matematycy polscy $w$ dwudziestoleciu międzywojennym Studium Historyczne, Kielce 2011 (według indeksu).

5 K. Tatarkiewicz, Uwagi o historii dwóch wieków mechaniki w Polsce, [w:] Matematyka Polska w stuleciu 1851-1950, Materiały z IX Ogólnopolskiej Szkoły Historii Matematyki. Międzyzdroje 5-9 czerwca 1995, red. S. Fudali, Szczecin 1995. 
PAN i PAU, Archiwum Uniwersytetu Jagiellońskiego. Nieliczne materiały zachowały się w Archiwum Obwodowym we Lwowie, Centralnym Archiwum Wojskowym i Archiwum Polskiej Akademii Nauk, Oddział w Poznaniu. Szukano także materiałów na jego temat w Archiwum Zakładowym PKP w Sosnowcu, Archiwum Instytutu Pamięci Narodowej, Stacji Muzeum w Warszawie, Archiwum Narodowym w Krakowie i Archiwum Państwowym w Lublinie.

Rodzina Vetulanich przybyła do Polski w XVIII wieku z Włoch. Od drugiej połowy XVIII wieku ,byli w Bochni średnim i wyższym nadzorem górniczym"6. Dziadek przyszłego kierownika budowy pociągów pancernych Michał Vetulani miał dwie córki i trzech synów. Wszyscy założyli rodziny. Ojciec Kazimierza, Roman Laurenty, urodził się 8 sierpnia 1849 roku ${ }^{7}$. Od 1875 roku był nauczycielem w II gimnazjum we Lwowie, a następnie, od 1883 roku, w Gimnazjum Męskim w Sanoku. Uczył języka łacińskiego, polskiego, niemieckiego, greckiego ${ }^{8}$, angielskiego i gimnastyki. Był między innymi autorem podręczników szkolnych do tych dwóch ostatnich przedmiotów i współzałożycielem Towarzystwa Gimnastycznego „Sokół” w Sanoku? Ożenił się z dużo młodszą od siebie Matyldą Marią, córką bocheńskiego drukarza Laurentego Pisza ${ }^{10}$.

Brat Romana Vetulaniego - Franciszek Ksawery Adam studiował na Akademii Technicznej we Lwowie (późniejszej Politechnice Lwowskiej) ${ }^{11}$. Wykorzystując swe wykształcenie hydrotechniczne pracował w czasie zaborów jako urzędnik w Krakowie i Lwowie. W latach 1918-1921 był zatrudniony w Ministerstwie Rolnictwa i Reform Rolnych w Warszawie. Miał czworo dzieci: Zofię Julię, Stanisława (prawdopodobnie kolegę gimnazjalne-

${ }^{6}$ M. Rotkiewicz, Mózg i błazen. Rozmowa z Jerzym Vetulanim, Wołowiec 2015, s. 8.

7 Archiwum Nauki PAN i PAU (AN) Spuścizna A. Vetulaniego (AV), sygn. 186, Materiały Biograficzne rodziny Vetulanich, b.d.; ibidem, kopia odpisu aktu urodzenia Romana Laurentego Vetulaniego (cytowane materiały z tego archiwum nie mają foliacji). Można też spotkać inną datę: 8 września 1949 roku.

8 Archiwum Obwodowe we Lwowie (AOL), sygn. 27/5/2190A Pismo Franciszka K. Vetulaniego do Kolegium Profesorów Szkoły Politechnicznej we Lwowie „na ręce p. Romana Vetulaniego Profesora II gimnazjum we Lwowie" z 1 października 1882, k. 1a; II Państwowe Liceum i Gimnazjum im. K. Szajnochy we Lwowie (nr 560) (lata szkolne 1819/1820-1938/1939). Dokumenty przeszłości, oprac. J. Kowalczuk, Kraków 2008, s. 315, 323, 441.

9 E. Zając, Vetulani Roman (1849-1908), pedagog, autor podręczników szkolnych, organizator pracy oświatowo-patriotycznej, [w:] Stownik biograficzny twórców oświaty i kultury XIX i XX wieku Polski potudniowo-wschodniej. Suplement, red. K. Szmyd, Rzeszów 2015, s. $140-141$.

10 Archiwum Akt Nowych (AAN), Ministerstwo Wyznań Religijnych i Oświecenia Publicznego (MWRiOP), sygn. 6366, k. 39.

11 AOL, sygn. 27/5/2190A, k. 13. 
go wybitnego matematyka Stefana Banacha ${ }^{12}$ ), Marię oraz Cecylię Karolinę. Potomstwo miał też między innymi kolejny brat Romana Vetulaniego ${ }^{13}$.

Kazimierz Franciszek Vetulani był najstarszym dzieckiem Romana Vetulaniego. Data jego urodzin jest w literaturze sporna, choć według akt studenckich przyszedł na świat w Sanoku 3 stycznia 1889 roku $^{14}$. Co ważne, jego ojcem chrzestnym był wspomniany brat Romana - Franciszek.

Wkrótce — w roku 1891 roku — zmarła matka Kazimierza ${ }^{15}$. Ojciec ożenił się powtórnie w 1893 roku. Z Karoliną Elżbietą z domu Kunachowicz ${ }^{16}$ doczekał się pięciorga dzieci: Zygmunta Michała (1894-1942), Tadeusza Bolesława (1897-1952), Adama Joachima (1901-1976), Marii (1895-1945) oraz Elżbiety (1903-1920/1921) ${ }^{17}$. Ojciec Kazimierza zmarł w sierpniu 1906 roku $^{18}$, a opiekę prawną nad przyszłym specjalistą od pociągów pancernych wkrótce objął jego ojciec chrzestny ${ }^{19}$. Kazimierz ukończył gimnazjum męskie w Sanoku ${ }^{20}$. Na świadectwie na dziesięć ocen miał osiem celujących i dwie bardzo dobre. Zwrócić należy jednak uwagę na zaledwie „dobre” zachowanie. Wskazuje to na trudny charakter młodego człowieka. Dnia 15 czerwca 1907 roku zdał z odznaczeniem egzamin dojrzałości ${ }^{21}$.

Być może za namową ojca chrzestnego, w październiku 1907 roku Vetulani rozpoczął studia na Wydziale Inżynierii Dróg i Mostów późniejszej Politechniki Lwowskiej (PL). Być może przyszły inżynier utrzymywał się sam (korepetycje, pisanie prac dyplomowych). Już 17 lipca 1909 roku zdał

12 Odnośnie do Stanisława Vetulaniego zgadza się wiek, imię, nazwisko i ówczesne miasto zamieszkania (por. M. Albiński, Wspomnienia o Banachu i Wilkoszu, „Wiadomości Matematyczne" 19, 1976, s. 134).

13 Najszerzej na ich temat R. Syrwid, „Ambasadorka Watykanu”, czyli Cecylii Vetulani potyczki z władza ludową. Nieznany list do Komisji Kultury Wojewódzkiej Rady Narodowej w Olsztynie z 1955 roku, „Komunikaty Mazursko-Warmińskie” 2 (276), 2012, 375-380.

14 AOL, sygn. 27/5/2190A, k. 1. Zbieżny pogląd zob. Z. Popławski, Wykaz..., s. 196; M. Walczak, op. cit., s. 150. Inne daty to 1879, 1880 lub 2 stycznia 1889 roku (między innymi D. Schenk, Noc morderców. Kaźń polskich profesorów we Lwowie i holokaust w Galicji Wschodniej, Kraków 2011, s. 167, 353; L. Maligranda, J. G. Prytuła, op. cit., s. 53).

15 AOL, sygn. 27/4/107, k. 1; zob. L. Maligranda, J.G. Prytuła, op. cit., s. 53. Inna podawana data to 1889 rok.

16 AN, AV, sygn. 186 Kopia odpisu aktu małżeństwa Romana Vetulaniego i Karoliny Elżbiety Kunachowicz.

17 M. Rotkiewicz, op. cit., s. 8; E. Dziurzyńska, Adam Vetulani (1901-1976), [w:] Korespondencja Adama Vetulaniego z Miroslavem Bohackiem, oprac. E. Dziurzyńska, M. Sumova, Kraków 2017, s. 14.

18 AOL, sygn. 27/4/107, k. 1; AN, AV, sygn. 186, Genealogia rodziny Vetulanich z Sanoka; zob. też E. Dziurzyńska, op. cit., s. 13. Inne podawane daty zgonu: 12 sierpnia 1908 i 1910 rok.

19 AOL, sygn. 27/5/2190A, k. 1.

20 Sanok. Dzieje miasta, red. F. Kiryk, Kraków 1995, s. 577.

21 AAN, MWRiOP, sygn. 6366, k. 40-42; zob. E. Zając, op. cit., s. 140. 
pierwszy egzamin rządowy z oceną ,znamienicie uzdolniony”22. Na studiach był jednym z licznych uczniów Maksymiliana Tytusa Hubera ${ }^{23}$. W 1911 roku, jeszcze jako student, opublikował w kilku częściach swój pierwszy, wysoko oceniany wówczas przez specjalistów artykuł we lwowskim „Czasopiśmie Technicznym”24. Studia przerwał w 1913 roku, co wynikało prawdopodobnie $\mathrm{z}$ jego trudnego charakteru.

Przed I wojną światową odbył „podróże naukowo-techniczne” do Włoch, a następnie po niemieckiej i czeskiej części ówczesnych Austro-Węgier i II Rzeszy. Zwiedzał w ich trakcie budowy wielkich mostów, zapór, bulwarów, analizował przeprowadzane wówczas regulacje rzek $^{25}$. Podróżowanie i zdobywanie doświadczeń zawodowych ułatwiały mu, odziedziczone po ojcu, zdolności językowe.

Poza niemieckim i angielskim nauczył się języka francuskiego i włoskiego (z którego tłumaczył teksty naukowe). Przed 1938 rokiem poznał także, choć słabiej, rosyjski i hiszpański ${ }^{26}$.

Być może za sprawą swojego zaangażowanego w Polskich Drużynach Strzeleckich brata Zygmunta ${ }^{27}$, w pierwszej połowie 1914 roku Kazimierz wykładał w Wiedniu minerstwo oraz wysadzanie w powietrze mostów i kolei na kursach oficerskich tej organizacji niepodległościowej ${ }^{28}$.

Wojna światowa rozdzieliła rodzeństwo. Kazimierz i Tadeusz służyli w wojsku austriackim, natomiast Zygmunt pracował kolejno w kontrolowanej przez Rosjan Warszawie, Charkowie i leżącym jeszcze dalej na wschód Słowiańsku ${ }^{29}$. Dla wdowy z młodszymi dziećmi wojna to „okres nawet nie biedy, ale wręcz skrajnej nędzy"30.

Kazimierz w czasie I wojny światowej oraz wojny Polski z bolszewikami

prowadzi i wykonuje szereg robót inżynierskich oraz inżyniersko-mechanicznych: budowa i przebudowa kolei normalnych z mostami, kolei motorowych, wąskotorowych motorowych i parowych, napowietrznych kolejek wiszących, różnych urządzeń transportowych i przeładowczych lądowych i lądowo-morskich tj. portowych, a także urządzeń dodatkowych zaopatrzenia w wodę, urządzeń warsztatowych, urządza mechaniczne produkcje tłucznia oraz prowadzi ro-

22 AOL, sygn. 27/5/2190A, k. 1.

23 Między innymi Archiwum Uniwersytetu Jagiellońskiego (AUJ), Wydział Filozoficzny Uniwersytetu (WF), sygn. 121 Pismo Dziekana WF do M. T. Hubera z 8 marca 1937 (teczka nie jest spaginowana).

24 AAN, MWRiOP, sygn. 6366, k. 24.

25 L. Maligranda, J.G. Prytuła, op. cit., s. 53.

26 AOL, sygn. 27/4/107, k. 1.

27 Zob. H. Bagiński, U podstaw organizacji Wojska Polskiego 1908-1914, Warszawa 1935 , s. 598,602 .

28 AOL, sygn. 27/4/107, k. 1; L. Maligranda, J. G. Prytuła, op. cit., s. 53.

29 Słownik biograficzny polskiej stużby zagranicznej 1918-1945, t. 1, oprac. K. Smolana, Warszawa 2007, s. 120.

30 M. Rotkiewicz, op. cit., s. 10.

Wrocławskie Studia Wschodnie 24, 2020

(C) for this edition by CNS 
boty minerskie dla eksploatacji kamieniołomów, budowy kolei i wysadzania obiektów. Prowadzi i organizuje transporty lądowe rzeczne i morskie dla celów intensyfikacji budowy, wprowadza niejednokrotnie naukową organizację pracy przy budowie i warsztatach ${ }^{31}$.

Zdobyte kompetencje i zdolności ułatwiły uzyskanie w trakcie służby w pułku kolejowym zaborcy awansu na oficera, brązowego medalu zasługi wojskowej „signum laudis” i złotego krzyża zasługi. Z dniem 1 listopada 1917 roku został przeniesiony do rezerwy ${ }^{32}$. Umożliwiło mu to powrót na studia w roku akademickim 1917/1918. Nie ukończył ich jednak ${ }^{33}$ — ,absolwent [...] bez egzaminu dyplomowego" 34 , „brak drugiego egzaminu i tytułu inżyniera" $" 35$.

W listopadzie 1918 roku wstąpił do Wojska Polskiego. Za udział w obronie Lwowa otrzymał odznakę Orlęta. Uzasadnieniem było „zmontowanie czy współzmontowanie pociągu pancernego, który podówczas w tej obronie odegrał ważną rolę"36. Lata 1918-1920 uznaje się za „złoty okres” rozwoju tego rodzaju broni w Polsce. W czasie „wojny 1919 r. jeden pociąg [pancerny - przyp. T.S.] mógł samodzielnie patrolować i ubezpieczać odcinek frontu długości $10 \mathrm{~km}$ "37. Zważywszy na przebieg wojny polsko-ukraińskiej, budowa pociągów pancernych w Lwowie miała bardzo istotne znaczenie wojskowe. Wyprodukowano tam tyle samo, lub więcej, lokomotyw pancernych co w Nowym Sączu (będącym najważniejszym ośrodkiem budowy pociągów pancernych w kraju ${ }^{38}$ ) i niewiele mniej wagonów pancernych. W 1918 roku Vetulani budował pociągi pancerne w Przemyślu ${ }^{39}$ — choć znaczenie ośrodka przemyskiego pod względem ilościowym było zdecydowanie mniejsze, to jednak dokonywane tam naprawy miały istotny wpływ na wykorzystanie pociągów pancernych w walkach wojska polskiego o uzyskanie i utrzymanie połączenia lądowego $\mathrm{z}$ oblężonym Lwowem. Wąski atakowany przez Ukraińców „korytarz” łączący Przemyśl z Lwowem był położony wzdłuż linii kolejowej ${ }^{40}$. Równocześnie co najmniej do kwietnia 1919 roku Przemyśl

31 AOL, sygn. 27/4/107, k. 1.

32 Ranglisten des Kaiserlichen und Köninglichen Heeres 1918. Abgeschlossen mit Personalverordnungsblatt $n r$ 40/18, Vien 1918, s. 236, 1478

33 L. Maligranda, J.G. Prytuła, op. cit., s. 53.

34 Archiwum Akademii Górniczo-Hutniczej (AAGH), Protokoły posiedzeń Ogólnego Zebrania Kolegium Profesorów Akademii Górniczej (PPOZKPAG), sygn. 17/3, s. 2.

35 AAGH, Akta Osobowe, sygn. 13/413, s. 13.

36 AN, AV, sygn. 45, A. Vetulani, Wrześniowa tułaczka, k. 9.

37 T. Krawczak, J. Odziemkowski, Polskie pociagi pancerne 1918-1939, „Przegląd Wojskowo-Historyczny" 24, 1979, nr 4, s. 121, 128 (cytat).

38 A.J. Ostrówka, Pociagi pancerne Wojska Polskiego 1918-1939, Torun 2013, s. 53; L. Zakrzewski, Pociagi pancerne z Warsztatów Głównych w Nowym Saczu, [w:] Kolejarze polscy dla niepodległej ojczyzny, Kraków 2018, s. 114.

39 AAN, MWRiOP, sygn. 6366, k. 24.

40 Por. J. Magnuski, Pociag pancerny Śmiaty w trzech wojnach, Warszawa 1996, s. 9-15.

Wrocławskie Studia Wschodnie 24, 2020

(C) for this edition by CNS 
był podstawowym, wraz z Warszawą, miejscem docelowym wysyłanych z Nowego Sącza wagonów i parowozów.

Rola Vetulaniego w działaniach wojennych na wschodzie była jednak zdecydowanie poważniejsza. Jeszcze w listopadzie 1918 roku z polecenia władz wojskowych ${ }^{41}$ rozpoczął w warsztatach kolejowych w Nowym Sączu kierowanie pracą co najmniej 150 robotników i 5 inżynierów budujących i naprawiających pociągi pancerne ${ }^{42}$. Jak pisano po latach, do pracy ,,warunki były idealne, gdyż byli wykwalifikowani rzemieślnicy kolejowi i odpowiednie warsztaty". Pracę ułatwił Henryk Suchanek, który między innymi motywował pracowników oraz ,przydzielał do pomocy por. Vetulaniemu inżynierów i werkmistrzów kolejowych" ${ }^{43}$. Już 22 grudnia 1918 roku wnioskowano, by „Naczelne Dowództwo udzieliło pisemną pochwałę i uznanie dla [tamtejszych - przyp. T.S.] urzędników i robotników, za bardzo intensywne i chętne wykonywanie pracy"44.

Jak pouczano 3 grudnia 1918 roku kierującego tą „ekspozyturą szefa inżynierii” w Krakowie: odnośnie do konstrukcji opancerzonych lokomotyw, wozów pancernych dla piechoty, wozów sanitarnych, wozów oficerskich oraz kuchni „są miarodajne wytyczne omówione z porucz[nikiem] Vetulanim (jako to strzelnice, opancerzenia, wyjścia, w podłodze, tapczany, drzwi itp.)"45. Wynika z tego, że Vetulani pełnił wówczas funkcję konstruktora w kierownictwie budowy pociągów pancernych, które obejmowało wówczas niemal cały Okręg Generalny Krakowski. W wojskowej służbowej korespondencji z tego okresu tytułowano go porucznikiem i inżynierem.

Prawdopodobnie Vetulani był kierownikiem powołanego na początku kwietnia 1919 roku nowosądeckiego Kierownictwa Budowy Pociągów Pancernych $^{46}$. Z omawianą funkcją związana była zapewne część robót inżynieryjnych wymienionych wcześniej odnośnie do I wojny światowej. W okresie największych sukcesów wojennych bolszewików sytuacja na froncie wymagała, by ,niezwłocznie zarządzić w tych warsztatach pracę na dwie

41 Centralne Archiwum Wojskowe (dalej: CAW), Kolekcje rękopisów, sygn. I.400. 2105, k. 37, 154, 155.

42 L. Zakrzewski, op. cit., s. 110. Była to jedna ósma ogółu pracowników warsztatów (CAW, Kolekcje rękopisów, sygn. I.400. 2105, k. 155). Pominięcie go w latach siedemdziesiątych w wykazie „,wybitniejszych inżynierów pracujących dłuższy czas w warsztatach sądeckich” (Z. Romańska, R.B. Romański, Z przeszłości kolejnictwa w Nowym Sączu (wspomnienia), „Rocznik Sądecki” 15/16, 1974-1977, s. 462-463) wynika z roli pociągów pancernych z Nowego Sącza w wojnie polsko-bolszewickiej i krótkiego czasu pracy Vetulaniego w Nowym Sączu.

43 CAW, Kolekcje rękopisów, sygn. I.400. 2105, k. 8 (2 cytaty).

44 Ibidem, k. 13.

45 Ibidem, k. 10.

46 Między innymi ibidem, k. 22. 
nawet na trzy zmiany by roboty dla frontu uskutecznić w najszybszym tempie"47. Mimo złej sytuacji finansowej państwa w 1920 roku w Nowym Sączu wybudowano nowe warsztaty dla parowozów o 12 stanowiskach (dotąd były $23)^{48}$. Poważną przeszkodą w terminowym zakończeniu prac przy poszczególnych pociągach pancernych były opóźnienia dostaw niezbędnych do tego materiałów.

Koncentracja na wspomnianych działaniach sprawiła, że w czasie pobytu w Nowym Sączu Vetulani nie angażował się na większą skalę w działalność funkcjonujących $\mathrm{w}$ mieście organizacji społecznych ${ }^{49}$. Znamienne, że do korespondencji podawał krakowski adres przy ulicy Smoleńsk ${ }^{50}$.

Przed połową 1921 roku $^{51}$ awansowano go w korpusie oficerów kolejowych do stopnia kapitana ze starszeństwem od 1 czerwca 1919 roku ${ }^{52}$. Najpóźniej od jesieni 1920 prowadził w Krakowie wykłady w Wyższej Szkole Technicznej Wojsk Kolejowych oraz na kursach dla oficerów (zawodowych oraz rezerwy) ${ }^{53}$. W preliminarzu wydatków na szkolnictwo wojsk kolejowych na wrzesień i październik 1921 roku nie jest on jednak uwzględniony. Być może zastępował swego promotora. Profesor Huber miał mieć bowiem wykłady z mechaniki ogólnej oraz mechaniki technicznej ${ }^{54}$.

Dnia 19 września 1919 roku został wybrany na członka Towarzystwa Matematycznego w Krakowie. Nie odgrywał w nim jednak większej roli ${ }^{55}$, nie tylko ze względu na zaangażowanie $\mathrm{w}$ prace nad budową pociągów pancernych w Nowym Sączu. Według Stanisława Gołębia Vetulani oraz między innymi Tadeusz Banachiewicz, profesor zwyczajny na Uniwersytecie Jagiellońskim, wybitny znawca astronomii, matematyki i geodezji ${ }^{56}$, należeli

47 CAW, Departament Techniczny Ministerstwa Spraw Wojskowych, sygn. I 300.41.151, Telegram Warszawskiej Dyrekcji Kolejowej do Dyrekcji Kolejowej Kraków z 12 sierpnia 1920.

48 Z. Romańska, R.B. Romański, op. cit., s. 451.

49 Milczą na jego temat obszerne i szczegółowe publikacje omawiające ówczesną działalność społeczną w Nowym Sączu (T. Aleksander, Życie społeczne i przemiany kulturalne Nowego Sącza w latach 1870-1990, Kraków 1993 (według indeksu); Dzieje miasta Nowego Sącza, red. F. Kiryk, Z. Ruta, Kraków 1996, t. 3 (według indeksu); J. Leśniak, Nowa encyklopedia sądecka, Nowy Sącz 2017, s. 888-889).

50 Bywała ona wówczas nazywana ulicą Smoleńską.

51 AAGH, Akta Osobowe, sygn. 13/413, k. 5.

52 Rocznik oficerski rezerw 1934, reprint, Warszawa-Londyn 2003, s. 281.

53 AAN, MWRiOP, sygn. 6366, k. 54.

54 CAW, Oddział IV Zaopatrzenia i Komunikacji Ministerstwa Spaw Wojskowych, sygn. I 300.10.03, Pismo II Departamentu Ministerstwa Spraw Wojskowych do Wydziału Rozrachunkowo-Kontrolnego Ministerstwa z 20 lipca 1921.

55 J. Piórek, Z protokołów Towarzystwa Matematycznego w Krakowie, „Matematyka. Społeczeństwo Nauczanie” 1989, nr 3, s. 4-10.

56 Szerzej o jego pozycji naukowej zob. np. T. Skrzyński, Aktywność Tadeusza Banachiewicza na posiedzeniach walnych i w pracach Wydzialu Matematyczno-Przyrodniczego Polskiej 
do takich członków Towarzystwa Matematycznego w Krakowie (a następnie ogólnokrajowego Polskiego Towarzystwa Matematycznego), „którzy nie byli par excellence matematykami" 57 .

Można przypuszczać, że Vetulani należał wówczas do Stowarzyszenia Inżynierów i Techników Mechaników Polskich oraz Krakowskiego Towarzystwa Technicznego. Nie zaliczał się jednak do ich czołowych działaczy ${ }^{58}$. W owym czasie uniemożliwiał to między innymi brak egzaminu dyplomowego ${ }^{59}$. Być może Vetulani, tak jak jego bracia Adam i Zygmunt, miał kontakty z Towarzystwem Oświaty Ludowej - taką możliwość oferował mu na przykład Nowy Sącz, gdzie działało ono w środowisku kolejarzy.

W pierwszej połowie 1921 roku Vetulani otrzymał pracę w Warszawie jako ,inżynier szef działu budowalnego polskiej spółki inżynierów"60 i wynajął mieszkanie w stolicy przy ulicy Polnej 76/6.

Równolegle, między czerwcem a wrześniem 1921 roku, toczyły się negocjacje w sprawie objęcia przez Vetulaniego Katedry Mechaniki Technicznej na Akademii Górniczej. W marcu 1921 roku odrzucono kandydaturę pracującego do niedawna w krakowskim kierownictwie budowy pociągów pancernych $^{61}$ Michała Affanasowicza ze względu na małą wartość skryptów wykładowych. Zrezygnowano z pomysłu, by wykłady i ćwiczenia prowadził Jan Jakub Stock, i zdecydowano, że katedrę obejmie Huber. W razie odmowy z jego strony postanowiono „szukać zastępcy profesora wśród sił miejscowych". Po odrzuceniu propozycji przez Hubera, i zapewne za jego sugestią, zdecydowano się 6 lipca na Vetulaniego jako zastępcę profesora na rok akademicki 1921-1922. Zainteresowany zwlekał jednak z podjęciem ostatecznej decyzji. We wrześniu rozważano więc także kandydatury Michała Affanasowicza i Zygmunta (?) Ciechanowskiego oraz powierzenie wykładów Janowi Jakubowi Stockowi ${ }^{62}$.

Ostatecznie w efekcie negocjacji 1 października 1921 roku Kolegium Profesorskie zdecydowało, by ze względu ,na niewątpliwe kwalifikacje kandydata $\mathrm{w}$ zakresie mechaniki oraz na trudne jego położenie materialne $[\ldots]$

Akademii Umiejętności w latach 1919-1952, „Studia Historyczne” 58, 2015, nr 3, s. 367-387; tam też dalsza literatura przedmiotu.

57 S. Gołąb, Z dziejów założenia Polskiego Towarzystwa Matematycznego, „Wiadomości Matematyczne" 4, 1961, s. 156.

58 Księga SIMP. Pól wieku działalności mechaników polskich w przemyśle, Warszawa 1963, s. 154-180, 287-325, 401-402.

59 Por. J. Piłatowicz, Ruch stowarzyszeniowy inżynierów i techników polskich do 1939 r., t. 2. Stownik polskich stowarzyszeń technicznych i naukowo-technicznych do 1939 r., Warszawa 2005, s. 45.

${ }^{60}$ AAGH, Akta Osobowe, sygn. 13/413, k. 3.

61 Należy się jednak zastrzec, że w dokumentacji wojskowej nie podaje się jego imienia.

62 AAGH, PPOZKPAG, sygn. 17/2, s. 39, 44, 58 (cytat), 63-64, 75, 84. 
przyjąć p. Vetulaniego jako asystenta zwyczajnego z płacą zastępcy profesora" ${ }^{\prime 3}$. Z powodu braku dyplomu inżyniera nie chciano przyznać mu tytułu zastępcy profesora. Dlatego formalnie nie obsadzono Katedry Mechaniki ${ }^{64}$ władze Akademii pragnęły „uniknąć precedensu na przyszłość”. Wobec tego, że ,praca drukowana z zakresu mechaniki czyni go ukwalifikowanym do prowadzenia wykładów i ćwiczeń" 65 , od października Vetulani został faktycznym szefem katedry z pensją zastępcy profesora. Miał prowadzić wykłady i ćwiczenia z mechaniki technicznej ${ }^{66}$ i ogólnej, formalnie będąc asystentem mechaniki. Uzgodnienia rektora i Kolegium Profesorów odnośnie do prowadzenia wykładów i pensji zostały podważone na szczeblu ministerstwa. Emocjonalne podejście Vetulaniego odnośnie do ukończenia studiów uniemożliwiało mu w najbliższych latach uzyskanie dyplomu. Władze Akademii Górniczej powierzyły mu więc wykłady z mechaniki ogólnej i technicznej formalnie jako asystentowi ,pod kierunkiem” dziekana Jana Jakuba Stocka. Równocześnie postanowiły przyznać mu znaczną liczbę godzin zleconych ${ }^{67}$. Zaakceptowano pomysł Vetulaniego, by częścią z nich był wykład z wybranych działów teorii wytrzymałości ${ }^{68}$. Równocześnie Vetulani pełnił faktycznie obowiązki kierownika katedry ${ }^{69}$; zakładał, że jest to początek dłuższej współpracy. Zamieszkał w Krakowie z większością rodzeństwa i macochą przy ulicy Smoleńsk $10^{70}$ (być może już wówczas na reprezentacyjnym pierwszym piętrze) ${ }^{71}$. Nieprzypadkowo od 1922 roku, podpisując dokumenty i publikując teksty, używał obu imion ${ }^{72}$.

Znając zapewne zastrzeżenia Akademii wobec Michała Affanasowicza, opracował i wydał w 1922 roku nakładem Ministerstwa Wyznań Religijnych i Oświecenia Publicznego (MWRiOP) liczący 330 stron skrypt zatytułowany:

${ }^{63}$ AAGH, PPOZKPAG, sygn. 17/3, s. 2-3.

${ }^{64}$ Z dziejów Akademii Górniczo-Hutniczej w Krakowie w latach 1919-1967, Kraków 1970, s. 40, 42.

${ }^{65}$ AAGH, Akta Osobowe, sygn. 13/413, k. 13 (oba cytaty).

${ }^{66}$ Z dziejów Akademii, s. 42.

${ }^{67}$ AAGH, Akta Osobowe, sygn. 13/413, s. 5, 19, 21, 23; AAGH, PPOZKPAG, sygn. 17/3, s. 33 .

${ }^{68}$ AAGH, Akta Osobowe, sygn. 13/413, s. 28; AN, AV, sygn. 186, Genealogia rodziny Vetulanich z Sanoka.

${ }^{69}$ W listopadzie 1922 roku pisano do niego: „Z powodu objęcia katedry mechaniki ogólnej przez [...] prof. inż. Dra[!] Michała Affanasowicza proszę o oddanie mu inwentarza i ksiąg rachunkowych katedry. Rozliczenie się z zaliczek z czasu prowadzenia katedry przez W. Pana proszę złożyć bezpośrednio w kwesturze" (AAGH, Akta Osobowe, sygn. 13/413, s. 35).

${ }^{70}$ AAGH, Akta Osobowe, sygn. 13/413, s. 42.

${ }^{71}$ K.F. Vetulani, O strugach cieczy, odbitka z „Czasopisma Technicznego”, Lwów 1933 (notatki na okładce egzemplarza w Bibliotece Jagiellońskiej).

72 AAGH, Akta Osobowe, sygn. 13/413, k. 3, 9, 15 (gdzie podpisywał się tylko jednym imieniem); Ibidem, k. 29-32, 43 (pisma podpisywane: „Kazimierz Fr. Vetulani”). 
Mechanika ogólna i techniczna. Cz. I. Rachunek punktów materialnych $i$ wektorów swobodnych ${ }^{73}$. Po latach uznano go za bardzo przystępny, oryginalnie ujęty oraz odznaczający się „ścisłością sformułowania twierdzeń i przeprowadzania dowodów"74. W czerwcu 1922 roku Vetulani prosił władze swej uczelni o sfinansowanie z subwencji bezzwrotnej „dla kandydatów dla profesorów" opracowania w czasie wakacji części drugiej i trzeciej skryptu jego wykładów (statyka i kinetyka) oraz opracowania wykładów z wytrzymałości materiałów ${ }^{75}$. Subwencji tej prawdopodobnie jednak nie otrzymał.

Sprawą obsady katedry na rok akademicki 1922/1923, którą kierował dotąd Vetulani, władze Akademii zajęły się we wrześniu i październiku 1922 roku $^{76}$. Zapewne ze względu na brak dyplomu Vetulaniego w listopadzie 1922 roku $^{77}$ Akademia, mimo wcześniejszych zastrzeżeń, zatrudniła na rok jako kierownika katedry Michała Affanasowicza. Vetulani pozostał jako asystent przy katedrze Mechaniki Ogólnej ${ }^{78}$. W tej sytuacji, zapewne ze względów ambicjonalnych lub (i) finansowych, Vetulani zrezygnował na przełomie listopada i grudnia 1922 roku z pracy w Akademii Górniczej ${ }^{79}$. Oficjalnie był zatrudniony do 31 grudnia 1922 roku.

Nie wiadomo, czy wiosną 1923 roku Rada Wydziału Górniczego brała ponownie pod uwagę kandydaturę Vetulaniego na pełniącego obowiązki kierownika omawianej katedry w roku 1923/1924. Na taką możliwość wskazują pośrednio wyniki głosowania w tej kwestii, nowa nazwa katedry: Mechaniki Ogólnej i Wytrzymałości Materiałów oraz lipcowe pismo z PL do Akademii Górniczej. Ostatecznie w czerwcu 1923 roku większością głosów zdecydowano, że katedrę obejmie specjalista od łodzi podwodnych Władysław Takliński ${ }^{80}$.

Dotychczasowa praca dała jednak Vetulaniemu dogodną podstawę do ubiegania się o stypendium na badania naukowe na Wydziale Komunikacyjnym PL. Nie dziwi to zważywszy, że był on kontynuacją wydziału, na którym Vetulani kilka lat wcześniej studiował. Środki te MWRiOP przyznało 1 czerw-

73 Za: L. Maligranda, J.G. Prytuła, op. cit., s. 56.

74 AAN, MWRiOP, sygn. 6366, k. 25.

75 AAGH, Akta Osobowe, sygn. 13/413, k. 31.

76 AAGH, PPOZKPAG, sygn. 17/3, s. 83.

77 Odpowiednie pismo wysłano do Vetulaniego 22 listopada, dzień po posiedzeniu ogólnym profesorów AG. Niemniej w protokole z posiedzenia na ten temat nie ma wzmianki. Protokół z październikowego zebrania Kolegium nie zachował się (AAGH, Akta Osobowe, sygn. 13/413, s. 35; AAGH, PPZKPAG, sygn. 17/4, s. 1-2).

78 Skład osobowy Akademii Górniczej w roku akademickim 1922/1923, październik 1922, [w:] A. Siwik, R. Artymiak, J. Kwiek, „Podejmując rozpoczęte dzieło...” Akademia Górnicza 1919-1939. Dokumenty, Kraków 2014, dok. 89, s. 277.

79 AAGH, Akta Osobowe, sygn. 13/413, s. 37.

80 AAGH, PPOZKPAG, sygn. 17/4, k. 9-10; AAGH, Akta Osobowe, sygn. 13/413, s. 41. 
ca 1923 roku w wysokości 2,1 miliona marek polskich ${ }^{81}$. Nie udało się ustalić, na jakie prace miały być one przeznaczone i czy Vetulani się z nich rozliczył. Przy ocenie przyznanej kwoty należy wziąć pod uwagę poziom ówczesnej hiperinflacji w Polsce.

Nie mógł liczyć na powrót do szkolnictwa wojskowego ze względu na jego znaczną redukcję związaną z demobilizacją. Nie oznaczało to jednak zakończenia kontaktów Vetulaniego z wojskiem. W 1923 roku został przydzielony w charakterze oficera rezerwy w 1 Pułku Wojsk Kolejowych. W kolejnym roku otrzymał przydział do 1 Pułku Saperów Kolejowych jako oficer rezer$w^{82}$. Po likwidacji wojsk kolejowych, co najmniej od 1934 roku należał do ośmiu kapitanów Korpusie Oficerów Inżynierii i Saperów przewidzianych w skali Polski „do użycia w czasie wojny” ${ }^{83}$.

Ze względów ambicjonalnych zakończenie pracy na uczelni było dla Vetulaniego bardzo trudne. W wielkiej księdze adresowej miasta Krakowa z 1925 roku figuruje nie jako inżynier, ale jako „prof." 84 . Był nieobecny na zorganizowanym przez Polskie Towarzystwo Matematyczne I polskim zjeździe matematycznym, który odbył się we wrześniu 1927 roku we Lwowie ${ }^{85}$. Czas załagodził uraz — w 1929 roku Vetulani wycofał swoje ,akta osobowe” z Akademii Górniczej ${ }^{86}$. W 1932 roku w książce adresowej Krakowa i województwa krakowskiego figurował tylko jako inżynier ${ }^{87}$.

Pracę znalazł jako „doradca techniczny dla szeregu większych firm, przedsiębiorstw oraz instytucji rządowych i samorządowych oraz dla klientów prywatnych" 88 . Projektował między innymi „budowle o charakterze przemysłowo transportowym". Wykonywał ekspertyzy i projekty eksploatacji kamieniołomów oraz „napowietrznych kolejek linowych”"89. Od czasu do czasu zaangażowany bywał też jako: prowadzący „roboty mostowe”; specjalista ekspertyz mostów kolejowych; , doradca techn[iczny] fabryk maszyn

81 AAGH, Akta Osobowe, sygn. 13/413, s. 41.

82 Prof. dr inż., kpt. rez WP II RP Kazimierz Franciszek Vetulani, https://www.ogrodywspomnien.pl/index/showd/109898\#book (dostęp: 4.04.2019).

83 Rocznik oficerski..., s. 936.

84 Wielka księga adresowa stoł. król. miasta Krakowa, Kraków 1925, s. 348. Miał wówczas mieszkać przy ulicy Smoleńsk, ale pod nr. 14 (ibidem). Numery Smoleńsk 10-14 niekiedy podawane były wówczas łącznie (np. AUJ, WF, sygn. 121, Pismo K. F. Vetulaniego do WF UJ z czerwca 1936).

85 Lista Uczestników zjazdu, [w:] Księga pamiątkowa pierwszego polskiego zjazdu matematycznego Lwów, 7-10.IX 1927, Kraków 1929, s. 2-6.

86 AAGH, Akta Osobowe, sygn. 13/413, s. 43.

87 Księga adresowa miasta Krakowa i województwa krakowskiego 1932, Kraków 1932, s. 547.

88 AOL, sygn. 27/4/107, k. 1; por. L. Maligranda, J.G. Prytuła, op. cit., s. 53-54.

${ }^{89}$ AOL, sygn. 27/4/107, k. 1 (2 cytaty). 
budowlanych i nowoczesnych maszyn do budowy komunikacji”,90, „wibratorów itp.”. Przeprowadzał również „trudniejsze obliczenia statystyczne”91. Równocześnie jednak w kilku źródłach wspomina się o trudnych warunkach materialnych, w jakich Vetulani żył w latach dwudziestych, i znacznych długach, jakie wówczas zaciągnął ${ }^{92}$.

Vetulani nie został członkiem najważniejszego — biorąc pod uwagę jego kwalifikacje — stowarzyszenia naukowców: Akademii Nauk Technicznych ${ }^{93}$. Nie był też członkiem Polskiej Akademii Umiejętności ani nie należał do żadnej z komisji w tej społecznej organizacji naukowej. Wiadomo tylko o jednym referacie Vetulaniego na tym forum, dotyczącym statystyki. W strukturze PAU do 1939 roku przeważały jednak nauki społeczne i humanistyczne. Komisję Nauk Technicznych powołano dopiero po II wojnie światowej.

Za granicą Vetulani publikował po włosku, niemiecku i hiszpańsku we Włoszech, Rumunii i Peru. Wygłaszał referaty naukowe między innymi we Francji i Rumunii. Najważniejszym przedmiotem jego zainteresowań badawczych były zagadnienia techniczne związane $\mathrm{z}$ wykonywaną pracą zawodową. W latach 1922-1934 ukazało się szesnaście publikacji naukowych technicznych i matematycznych Vetulaniego (i trzy za lata 1935-1937) ${ }^{94}$. Większość z nich dotyczyła teorii wytrzymałości, trzy mechaniki ogólnej, a dwie hydrodynamiki ${ }^{95}$. Wliczono do tego dwa druki w rodzaju datowanego na 22 sierpnia 1930 roku zatytułowanego: Orzeczenie techniczne o użyteczności kamienia z Mogielnicy da celów komunikacyjno-budowlanych ${ }^{96}$. Do tego należy dodać dwa thumaczone przez Vetulaniego teksty badaczy zagranicznych. Za jedną z jego najważniejszych publikacji w tym okresie Edward Zając uznaje $O$ strugach cieczy ${ }^{97}$ — uwagi do pracy uczonego włoskiego Tullia Leviego Civity pod tym samym tytułem, liczące 37 stron.

W 1938 roku na PL dysponowano wykazem 34 prac naukowych napisanych i wygłoszonych, ,z zakresu wszystkich działów mechaniki łącznie z hydrodynamiką" 98 . Część z nich nie została wydana drukiem, na przykład

90 Ibidem (2 cytaty).

91 AAN, MWRiOP, sygn. 6366, k. 25 (2 cytaty).

92 Między innymi AAN, MWRiOP, sygn. 6366, k. 61.

93 Por. J. Długosz, Polska Akademia Nauk Technicznych w Warszawie (1920-1939). Zarys dziejów, skład osobowy, osiagnięcia, Poznań 2002, s. 116.

94 L. Maligranda, J.G. Prytuła, op. cit., s. 55-57; W. Więsław, Listy Wacława Sierpińskiego do Stanisława Ruziewicza, „Wiadomości Matematyczne” 40, 2004, s. 162, przypis 43.

95 AAN, MWRiOP, sygn. 6366, k. 32.

96 K.F. Vetulani, Orzeczenie techniczne o użyteczności kamienia z Mogielnicy dla celów komunikacyjno-budowlanych, Warszawa 1931, s. 13.

97 E. Zając, op. cit., s. 140.

98 AAN, MWRiOP, sygn. 6366, k. 25. 
wygłoszony w Paryżu referat objaśniający po francusku „graficzny sposób obliczania uogólnionych belek Vierendeela"99.

Równolegle Vetulani utrzymywał kontakty z uczonymi z różnych ośrodków naukowych, między innymi ze specjalistą budownictwa wodnego i technik melioracyjnych (i byłym dyrektorem Studium Rolniczego Uniwersytetu Jagiellońskiego) Tadeuszem Sikorskim ${ }^{100}$. Kontakty Vetulaniego z matematykami lwowskimi były jednak rzadkie ${ }^{101}$.

Brat Vetulaniego Adam uważał go za znakomitego znawcę muzyki ${ }^{102}$. W omawianym okresie Vetulani wydał dwie publikacje na temat teorii skal muzycznych. Zważywszy na język prac (angielski i włoski) ${ }^{103}$, autor mógł zmierzać do dalszego rozwoju naukowego w kierunku teorii muzyki. Prace te nie zapewniły mu jednak trwałego miejsca w polskiej muzykologii ${ }^{104}$. W literaturze przedmiotu nie ma też informacji o jego zaangażowaniu w krakowskie struktury związane z muzyką ${ }^{105}$.

W latach 1921-1934 Vetulani utrzymywał bliskie kontakty z przynajmniej częścią rodzeństwa. Mieszkał w tej samej kamienicy co jego brat Adam i macocha lub w sąsiedniej. Adam był historykiem prawa - związał się z Uniwersytetem Jagiellońskim, tam zrobił doktorat, habilitację, a w 1934 roku został profesorem nadzwyczajnym; później natomiast objął kierownictwo Katedry Prawa Kościelnego. Był najbardziej w rodzinie związany z ruchem ludowym ${ }^{106}$. W Krakowie mieszkała też Maria - siostra Kazimierza, magister nauk ekonomicznych, pracująca w Banku Rolnym ${ }^{107}$.

Kazimierz utrzymywał też relacje $\mathrm{z}$ bratem Zygmuntem ${ }^{108}$. Ten ekonomista w latach 1920-1940 był kolejno wicekonsulem w Wiedniu i Królewcu, kierownikiem konsulatu, a następnie konsulem w Ostrawie (Czechosłowacja); radcą handlowym w Stambule (a następnie w Ankarze), konsulem w Bukareszcie,

99 Ibidem, k. 28.

100 K.F. Vetulani, W sprawie wyboczenia, odbitka z „Czasopisma Technicznego”, Lwów 1930, s. 1 (dedykacja na egzemplarzu zachowanym w Bibliotece Jagiellońskiej).

101 R. Duda, Lwowska szkoła matematyczna, Wrocław 2014, s. 7-224.

102 AN, AV, sygn. 186, Genealogia rodziny Vetulanich z Sanoka; zob. Zżycia i działalności Adama Vetulaniego 1901-1976. Katalog wystawy, Kraków 2001, s. 8.

103 L. Maligranda, J.G. Prytuła, op. cit., s. 57.

104 Zob. np. A. Rakowski, Kategorialna percepcja wysokości dźwięku w muzyce, Warszawa 1978, s. 7-159, 170. Nie wymieniono go na przykład w M. Chmielewska, Leksykon polskich pisarzy muzycznych XX wieku, Wołomin 2008.

105 Na przykład Kraków muzyczny 1918-1939, red. M. Drobner, T. Przybylski, Kraków 1980 (według indeksu).

106 Najszerzej Adam Vetulani 1901-1976 Materiaty z posiedzenia naukowego PAU w dniu 16 listopada 2001 r., red. R. Majkowska, Kraków 2005. Tam dalsza literatura przedmiotu.

107 E. Dziurzyńska, op. cit., s. 14.

108 AN, AV, sygn. 240, List Z. Vetulaniego do rodzeństwa w Krakowie z 20 marca 1920. 
a następnie (po okresie pracy w Warszawie w ministerstwie) w Bagdadzie. Opublikował wiele tekstów o charakterze propagandowym, przeznaczonych dla obcych czytelników (na przykład po turecku). Został także odznaczony przez władze polskie, węgierskie, rumuńskie i afgańskie ${ }^{109}$. Jak wynika z kartoteki osobowej w Centralnym Archiwum Wojskowym i wspomnień Adama Vetulaniego, w latach dwudziestych i trzydziestych był także powiązany z polskimi siłami zbrojnymi ${ }^{110}$.

Dobre były zapewne relacje Kazimierza Vetulaniego z bratem Tadeuszem. Po studiach, zaczynając od pracy zarządcy majątków ziemskich, pełnił on w okresie międzywojennym funkcję zastępcy profesora na Uniwersytecie w Wilnie, a następnie profesora nadzwyczajnego i kierownika Katedry Szczegółowej Hodowli Zwierząt na Uniwersytecie Poznańskim. Najbardziej znany był jako badacz koni. Swe najważniejsze prace publikował wówczas między innymi po niemiecku i turecku ${ }^{111}$.

O relacjach Kazimierza Vetulaniego z macochą pośrednio świadczy napis na klepsydrze Kazimierza z 1945 roku — „matka”"112.

W świetle dostępnych danych można przyjąć, że przed 1939 rokiem wszyscy kuzyni i kuzynki Kazimierza od strony ojca uzyskali lub podjęli próbę zdobycia wykształcenia wyższego. Adam habilitował się w roku 1928, a Tadeusz w $1929^{113}$. Jeśli do tego doliczymy rosnącą liczbę inżynierów z pełnymi kwalifikacjami, to nie dziwi, że Kazimierz Vetulani 15 kwietnia 1935 roku zdał egzamin dyplomowy inżyniera dróg i mostów na kierunku inżynierii lądowej na PL (z pisania elaboratu był zwolniony) ${ }^{114}$. Był to wstęp do starań Vetulaniego o doktorat z nauk technicznych — jeszcze w grudniu tego roku zdał egzamin doktorski ${ }^{115}$. Pojawiają się głosy, że jako ekscentryk nie chciał go zdawać „przed głupszymi od siebie”. W tej sytuacji „trzech profesorów zabrało go na przechadzkę po parku i wynik tej rozmowy uznali równocześnie za zdany egzamin doktorski"116.

Tytuł uzyskał 25 stycznia 1936 roku na Wydziale Inżynierii Lądowej i Wodnej PL. Jego promotorem był kierownik katedry mechaniki ogólnej PL

109 Stownik biograficzny polskiej stużby zagranicznej..., s. 120-121; Czy wiesz kto to jest?, red. S. Łoza, Warszawa 1938, s. 769; AN, AV, sygn.131 [!] Listy Z. Vetulaniego do A. Vetulaniego z 1939 i 1940.

110 CAW Kartoteki, karta o sygnaturze MN 17.03.1932 (odnośna teczka osobowa nie zachowała się); AN, AV, sygn. 45, A. Vetulani, Wrześniowa tułaczka, k. 10.

111 Szerzej na jego temat zob. np. W. Marmon, Vetulani Tadeusz, [w:] Stownik biograficzny historii Polski, t. 2. L-Ż, Wrocław-Kraków 2005, s. 1588-1589.

112 AN, AV, sygn. 322, Klepsydra K.F. Vetulaniego z 1945.

113 Na przykład W. Marmon, op. cit., s. 1588.

114 AAN, MWRiOP, sygn. 6366, k. 44.

115 AOL, sygn. 27/4/107, k. 1.

116 L. Maligranda, J.G. Prytuła, op. cit., s. 54.

Wrocławskie Studia Wschodnie 24, 2020

(C) for this edition by CNS 
Wojciech Rubinowicz. Podstawę stanowiły wydany w języku włoskim w 1933 roku tekst $O$ strugach cieczy i złożone „,z odznaczeniem” egzaminy ${ }^{117}$.

Najpóźniej w czerwcu 1936 roku podjął starania o uzyskanie habilitacji na Wydziale Filozoficznym UJ z mechaniki ogólnej i stosowanej. Podstawą miała być opublikowana w 1930 roku w „Czasopiśmie Technicznym” czterdziestostronicowa praca: $W$ sprawie wyboczenia ${ }^{118}$. Starania te ułatwiały publikacje, kontakty, a także doświadczenia zdobyte w czasie pracy na Akademii Górniczej. Miejsce starań było dobrze dobrane — na tym wydziale z nauk ścisłych habilitował się cały szereg osób. Wydział uzyskał w grudniu 1936 roku zgodę ze strony MWRiOP na przeprowadzenie habilitacji. W marcu 1937 roku o opinię poproszono dawnego mistrza habilitanta - Hubera oraz Stanisława Zarembę i Witolda Wilkosza. Ci ostatni mieli przedstawić swą opinię na najbliższym posiedzeniu Rady Wydziału Filozoficznego UJ ${ }^{119}$. Opinie wskazywały zapewne na przecenienie przez autora znaczenia wspomnianego artykułu. Sugerowały Vetulaniemu, aby rozszerzył podstawę habilitacji o kilka innych tekstów, zapewne o zbliżonej tematyce. Problemem nie do pokonania okazał się jednak charakter habilitanta. W sierpniu 1937 roku pisał do brata:

ja nie mam zamiaru żadnej dalszej pracy dołączać do sprawy habilitacyjnej jak to, co podałem, $\mathrm{i}$ to jest moje zupełnie zdecydowane stanowisko, o którym [dziekan Wydziału] L[echr]-Sp[ławiński] wie. [...] Uniwersytet może albo habilitację przyjąć, albo odrzucić! Na dalsze przewlekaniowe [!] kręcenie sprawy nie idę i nie pójdę ${ }^{120}$.

Ostatecznie, mimo pism Wydziału Filozoficznego do Hubera ze stycznia i kwietnia 1938 roku $^{121}$, Vetulani jeszcze w 1937 roku podjął starania o uzyskanie stopnia na innej uczelni. Trwały one jednak dość długo. Według jednego z jego listów do brata Adama z początku 1939 roku przeciąganie się sprawy wynikało z zakulisowych działań jego wrogów rozpuszczających szkodzące mu plotki. Dopiero w marcu 1939 roku Wydział Filozoficzny Uniwersytetu Jagiellońskiego oficjalnie uznał sprawę habilitacji Vetulaniego na tej uczeni za nieaktualną ${ }^{122}$.

W ramach starań o uzyskanie habilitacji na PL dzięki Funduszowi Kultury Narodowej Kazimierz wyjechał na badania naukowe kolejno do Niemiec, Belgii, Wielkiej Brytanii i Francji (22 czerwca — 10 października 1937

117 AAN, MWRiOP, sygn. 6366, k. 15; zob. też L. Maligranda, J.G. Prytuła, op. cit., s. 54.

118 AUJ, WF, sygn. 121, Pismo K. F. Vetulaniego do WF z czerwca 1936, k. 1.

119 Ibidem, Pisma Dziekana WF UJ do M.T. Hubera z 8 marca oraz S. Zaremby i W. Wilkosza z 9 marca 1937.

120 AN, AV, sygn. 240, Kartka K.F. Vetulaniego z sierpnia 1937.

121 AUJ, WF, sygn. 121, Pisma dziekana WF do M.T. Hubera z 25 stycznia i 25 kwietnia 1938.

122 AAN, MWRiOP, sygn. 6366, k. 69.

Wrocławskie Studia Wschodnie 24, 2020

(C) for this edition by CNS 
roku $)^{123}$, ,[Z]apoznał się [tam] z nowoczesną organizacją nauczania mechaniki, z laboratoriami oraz $\mathrm{z}$ zastosowaniem mechaniki $\mathrm{w}$ dziedzinie budowy kolei, z badaniem drgań mostów kolejowych i drgań gruntu budowlanego"124.

Z tym powiązane były starania Vetulaniego o prowadzenie Katedry Mechaniki Ogólnej na Wydziale Inżynierii Lądowej i Wodnej Politechniki. Kierujący nią Wojciech Rubinowicz przenosił się bowiem na Uniwersytet Lwowski ${ }^{125}$. Miał co najmniej dziesięcioro kontrkandydatów (dziewięciu doktorów i jednego magistra), mimo to odniósł sukces. W marcu 1938 roku odnośna komisja wnioskowała nie tylko o powołanie go na Katedrę Mechaniki Ogólnej, ale także o mianowanie profesorem zwyczajnym. Dnia 20 maja Senat PL rozpatrzył przychylnie oba wnioski Rady Wydziału ${ }^{126}$. Równocześnie, obawiając się przeszkód w MWRiOP, 8 kwietnia 1938 roku Rada Wydziału prosiła ministerstwo o powierzenie Vetulaniemu jedynie zastępstwa w omawianej katedrze ${ }^{127} .12$ lipca MWRiOP wyraziło zgodę na jego zatrudnienie w tym charakterze od 1 września 1938 roku ${ }^{128}$.

Mimo krótkiego okresu pracy na Politechnice Vetulani został zapamiętany przez studentów. Na wykładach z mechaniki ogólnej skupiał się szczególnie na współrzędnych naturalnych, środku masy, kinematyce punktu i układu sztywnego oraz statystyce. W obrębie tej ostatniej dużo miejsca poświęcał metodom wykreślnym ${ }^{129}$. Równocześnie prowadził na Wydziale Mechanicznym PL wykład i ćwiczenia z hydromechaniki oraz statykę konstrukcji i rysunki ze statyki konstrukcji. Równolegle na Wydziale Inżynierii Lądowej i Wodnej miał wykłady i ćwiczenia z wytrzymałości materiałów i hydromechaniki ${ }^{130}$. Ze względu na krótki okres prowadzenia zajęć jego działalność w zakresie hydromechaniki nie znalazła odzwierciedlenia w odnośnej monografii ${ }^{131}$.

Równolegle z pracą dydaktyczną posuwała się naprzód sprawa jego habilitacji. Dnia 7 czerwca 1939 roku na Radzie Wydziału odczytano pismo MWRiOP „W sprawie dokończenia habilitacji dra Vetulaniego” i zaakcepto-

123 Ibidem, k. 18.

124 AAN, MWRiOP, sygn. 6366, k. 25; zob. też L. Maligranda, J.G. Prytuła, op. cit., s. 54.

125 Z. Popławski, Dzieje Politechniki Lwowskiej 1844-1945, Wrocław 1992, s. 251-252, 253. Niekiedy omawiana struktura jest nazywana Katedrą Mechaniki Teoretycznej.

126 AAN, MWRiOP, sygn. 6366, k. 20, 26-27, 73.

127 Ibidem, k. 78.

128 Ibidem, k. 80-81. Zob. L. Maligranda, J.G. Prytuła, op. cit., s. 54.

129 W. Wojtkiewicz-Rok, Sylwetki uczonych polskich pomordowanych we Lwowie w lipcu 1941 r., [w:] Kaźń profesorów lwowskich - lipiec 1941. Studia oraz relacje i dokumenty, zeb. i oprac. Z. Albert, Wrocław 1989, s. 365.

130 Historia szkolnictwa, oświaty $i$ wychowania na ziemiach Odtaczonych II RP - Kresach Południowo-Wschodnich, t. 11. Politechnika Lwowska, oprac. J. Kowalczuk, Kraków 2013, cz. 3, s. 210, 244, 245, 248, 249, 260, 275, 281.

131 S. Juniewicz, Budownictwo Wodne na Politechnice Lwowskiej i Wrocławskiej, Wrocław 1987.

Wrocławskie Studia Wschodnie 24, 2020

(C) for this edition by CNS 
wano wniosek wybitnego hydrotechnika, byłego rektora PL Maksymiliana Matakiewicza co do wyboru referentów do oceny bardzo niewielkich rozmiarów pracy habilitacyjnej poświęconej wyboczeniom poziomym toru kolejowego na podłożach: płaskim, sztywnym i szorstkim ${ }^{132}$. W ślad recenzji Hubera z czerwca 1938 roku referenci ,ze względu na szczupłość przyczynku naukowego" uznali za konieczne objęcie wnioskiem także dwóch innych opracowań: Wybrzuszenie pionowe toru kolejowego ściskanego podtużnie traktowane elementarnie (niewydane) oraz Wybrzuszenie nieprzerwanego toru kolejowego traktowane z grubsza jako zjawisko quasi statyczne ${ }^{133}$. Już 14 czerwca Rada jednomyślnie podjęła stosowną decyzję. Ze względu na charakter Vetulaniego wcześniej podejmowano próby zwolnienia go z wykładu habilitacyjnego, ale sprzeciwiło się temu MWRiOP. Veniam legendi przyznano mu 17 czerwca. Decyzję Rady zatwierdziło ministerstwo, 31 lipca informując Vetulaniego, że został docentem mechaniki ogólnej i technicznej ${ }^{134}$.

Równolegle trwały starania o profesurę ${ }^{135}$. Do tak szybkiego awansu od uzyskania dyplomu inżyniera nie było wówczas przeszkód od strony prawnej ${ }^{136}$; dodatkowo Vetulaniemu sprzyjały jego dorobek, kontakty naukowe oraz stosowny wiek. Już 3 lipca 1939 roku PL wystąpiła do ministerstwa o nadanie mu tytułu „profesora zwyczajnego mechaniki ogólnej”"137.

Część badaczy uznaje, że już latem 1939 roku został kierownikiem Katedry Mechaniki Ogólnej ${ }^{138}$ i profesorem zwyczajnym ${ }^{139}$. Autorzy ci nie podają jednak, kiedy stosowną decyzję podjął Prezydent RP.

Po przyjeździe do Lwowa Kazimierz nadal utrzymywał dobre kontakty z rodzeństwem. Zacieśnił też relacje z kuzynami i ciotkami zamieszkałymi wówczas we Lwowie. Co najmniej od 1939 roku mieszkał samotnie przy ulicy Obertyńskiej 31, w mieszkaniu numer 5 na drugim piętrze ${ }^{140}$.

132 AAN, MWRiOP, sygn. 6366, k. 56.

133 Ibidem, k. 60-61, 63-64.

134 Ibidem, k. 45, 51, 66-67. Brudnopis pisma MWRiOP do K.F. Vetulaniego został sprawdzony 22 lipca, wysłany 31 lipca i złożony do registratury 4 sierpnia 1939. Data dzienna na kopii pisma wysłanego z MWRiOP do Vetulaniego jest nieczytelna (ibidem, k. 65).

135 AN, AV, sygn. 240, List K. Vetulaniego do A. Vetulaniego z 17 i 26 stycznia 1939.

136 Szerzej na ten temat J. Jastrzębski, Instytucja profesury zwyczajnej w polskim państwowym szkolnictwie akademickim w latach 1920-1939, Kraków 2018.

137 AAN, MWRiOP, sygn. 6366, k. 48-49.

138 Na przykład T. Skarżyński, Martyrologia, straty wojenne i okupacyjne środowiska Politechniki Lwowskiej (1918-1945), [w:] Politechnika Lwowska Macierz polskich politechnik, materiały z konferencji 25-26 września 1995, red. M. Sroczyński et al., Wrocław 1995, s. 172.

139 Na przykład Z. Popławski, Dzieje..., s. 282.

140 Między innymi AN, AV, sygn. 240 List K. F. Vetulaniego do A. Vetulaniego 26 stycznia 1939; Archiwum Polskiej Akademii Nauk (dalej: APAN), Oddział w Poznaniu, Spuścizna Tadeusza Vetulaniego, sygn. 104, k. 145.

Wrocławskie Studia Wschodnie 24, 2020

(C) for this edition by CNS 
Ze wspomnień brata wynika, że we wrześniu Vetulani nie został wezwany do stawienia się w szeregach Wojska Polskiego ${ }^{141}$. Jeśli tak było, to zapewne z powodu wówczas niewielkiego znaczenia pociągów pancernych, a także jego wieku. Być może $z$ ewidencji oficerów rezerwy skreślono go jeszcze przy okazji przenosin na stałe z Krakowa do Lwowa. Nieprzypadkowo nie ma go w wykazach strat korpusu oficerskiego w czasie II wojny światowej ${ }^{142}$.

W okresie okupacji Lwowa przez najeźdźcę ze wschodu Vetulani pełnił we Lwowskim Instytucie Politechnicznym funkcję kierownika Katedry ${ }^{143}$ w ramach Wydziału Budownictwa Drogowo-Wodnego. Według wiedzy tej części rodziny, która mieszkała wówczas we Lwowie, Kazimierz Vetulani był „ceniony i lubiany przez studentów” polskich, ukraińskich i żydowskich ${ }^{144}$. Miał też kontynuować badania naukowe ${ }^{145}$. Według większości opracowań w roku akademickim 1939/1940 ${ }^{146}$ po weryfikacji tytułów naukowych otrzymał radziecki odpowiednik profesora zwyczajnego. Zważywszy na jego wcześniejszy dorobek i pozycję, decydującym czynnikiem przy nominacji Vetulaniego były niedobory kadrowe bolszewików. Nie ma danych, by był w tym czasie zaangażowany politycznie ${ }^{147}$.

Mimo terroru okupantów utrzymywał kontakty z braćmi i siostrą pozostającymi w Krakowie ${ }^{148}$ oraz z kuzynami przebywającymi we Lwowie ${ }^{149}$. Mieszkał nadal pod tym samym adresem ${ }^{150}$, jednak jego warunki życia nie były najlepsze. Brat Zygmunt pisał z Bagdadu do Adama Vetulaniego: „Chcia-

141 AN, AV, sygn. 45, A. Vetulani, Wrześniowa tułaczka, k. 9.

142 T. Kryska-Karski, Straty korpusu oficerskiego 1939-1945, Londyn 1996, s. 453.

143 Na przykład Z. Popławski, Represje okupantów na Politechnice Lwowskiej, [w:] Lwów i lwowianie. Pamiętniki. Wspomnienia. Relacje, oprac. J. Kowalczuk, cz. 3, Kraków 2011, s. 309.

144 Za: L. Maligranda, J.G. Prytuła, op. cit., s. 55 (też cytat).

145 prof. dr inż., kpt. rez WP II RP Kazimierz Franciszek Vetulani...

146 J. Węgierski, J. Krawczyk, Wydział Inżynierii, [w:] Politechnika Lwowska 1844-1945, red. J. Boberski et al., Wrocław 1993, s. 127; R. Sroczyński, Politechnika Lwowska macierz polskich politechnik 1844-1994, [w:] Ksiega jubileuszowa 25-lecia Wykładów Historii Nauki i Techniki prof. dr hab. Ryszarda Sroczyńskiego, Wrocław 1997, s. 138, 153; por. np. R. Szewalski, Politechnika Lwowska w latach wojny i okupacji (1939-1945), [w:] Lwowskie środowisko naukowe w latach 1939-1945, red. I. Stasiewicz-Jasiukowa, Warszawa 1993, s. 27; Z. Popławski, Wykaz..., s. 196; W. Bonusiak, Kto zabit profesorów lwowskich?, Rzeszów 1989, s. 99.

147 Na przykład L'vìvs'ka politehnika v publikaciâh..., s. 128-129, 542.

148 Zob. AN, AV, sygn. 131 [!] Kartka Z Vetulaniego do A. Vetulaniego z 3 lutego i 14 marca 1940.

149 APAN, Oddział w Poznaniu, Spuścizna Tadeusza Vetulaniego, sygn. 104, k. 148; L. Maligranda, J.G. Prytuła, op. cit., s. 55.

150 APAN, Oddział w Poznaniu, Spuścizna Tadeusza Vetulaniego, sygn. 104, k. 148, 149; Relacja L. Szargułowej z 22 października 1971, [w:] Kaźń profesorów..., s. 315. 
łem do Kazika posłać paczkę żywnościową via Paryż i Rygę, ale są niesłychanie drogie [...] i to brak pewności, czy dojdzie"151.

Tragiczne zmiany przyniosła niemiecka okupacja. Według przekazów rodzinnych Vetulani mógł uniknąć aresztowania, do którego doszło 3 lipca został bowiem „,na czas ostrzeżony przez ukraińskich studentów, by przez parę dni najbliższych unikał okolicy swojego mieszkania i nie nocował w nim" 152 . Wziął jednak pod uwagę między innymi swoje kontakty z naukowcami niemieckimi ${ }^{153}$ i włoskimi, pochodzenie przodków z kraju, który był wówczas ważnym sojusznikiem III Rzeszy, jak również uważanie się części odległych krewnych po mieczu za Niemców ${ }^{154}$. Dobór osób podlegających kaźni odbywał się jednak według nieco innego klucza, niż zakładał, a koordynacja działań struktur III Rzeszy wobec naukowców lwowskich była niepełna ${ }^{155}$. W trakcie aresztowania Vetulani był przekonany o swoim bezpieczeństwie. Odniósł chwilowy sukces, nie przeprowadzono bowiem przeszukania mieszkania. W trakcie schodzenia po schodach aresztowany ,pogwizdywał cicho i lekceważąco"156. Taka postawa wywołała brutalną reakcję eskortujących: „profesor był przez nich bity i poniżany” 157 .

Ostatnia z prac złożonych do druku przez Vetulaniego ukazała się dziewięć lat po jego śmierci, w tomie wydanym ku czci jego mistrza Hubera. Według Edwarda Zająca pozostawione przez uczonego rękopisy poza Wstępem do rozprawy o problemie skal zostały zniszczone za sprawą hitlerowskiego okupanta $^{158}$.

Jak oceniano w 1938 roku, kwalifikacje teoretyczne i praktyczne pozwalały Vetulaniemu ,zajmować się bardzo zawiłymi i subtelnymi zagadnieniami. Przy zagadnieniach, których teoretyczne rozwiązanie jeszcze niezupełnie dojrzało, rozważa zawsze możliwości doświadczalnego rozstrzygnięcia punktów niejasnych lub spornych" ${ }^{159}$. Jego dorobek wskazywał na „wielki zapał do

151 AN, AV, sygn. 131, List Z. Vetulaniego do A. Vetulaniego z 14 marca 1940.

152 Cyt. za: L. Maligranda, J.G. Prytuła, op. cit., s. 55.

153 Ibidem.

154 Mieszkali oni w Rumunii. Przed II wojną światową rodzeństwo Kazimierza utrzymywało z nimi kontakty (AN, AV, sygn. 186, Materiały biograficzne rodziny Vetulanich).

155 Przykładem są spóźnione poszukiwania przez niemiecki wywiad wojskowy Stanisława Piłata, zabitego w ramach lipcowego mordu (A. Kuczyński, Z. Wójcik, Kaźń profesorów lwowskich, „Wrocławskie Studia Wschodnie” 2015, nr 19, s. 222).

156 Relacja L. Szargułowej..., s. 315. O tym, jak długo trwały rewizje, zob. też IPN Wr 587/162 K. Fiedor, Zbrodnie popetnione na profesorach lwowskich w lipcu 1941 r., k. 7-8.

157 Cyt. za: P. Łysakowski, Mord na profesorach lwowskich — lipiec 1941 r., „Dzieje Najnowsze" 2012, nr 3, s. 74.

158 E. Zając, op. cit., s. 140.

159 AAN, MWRiOP, sygn. 6366, k. 25. 
pracy badawczej” oraz odpowiednie zrozumienie „konieczności współpracy badań teoretycznych i doświadczalnych"160. Podczas swojej krótkiej pracy na Politechnice Lwowskiej nie zdążył wyrobić sobie tam mocnej pozycji naukowej.

Stan badań uniemożliwia obecnie wnikliwą ocenę dorobku Vetulaniego na tle porównawczym. Józef Piłatowicz nie zalicza go do wyróżniających się matematyków pracujących w okresie międzywojennym na Politechnice ${ }^{161}$, a według jednego z wybitnych znawców historii nauki dorobek naukowy Kazimierza Vetulaniego był mniej znaczący niż osiągnięcia w tym zakresie jego braci Tadeusza i Adama ${ }^{162}$. Niewykluczone jednak, że najważniejsze osiągnięcia Kazimierza Vetulaniego były związane z kierowaniem w czasie wojen budową pociągów pancernych i portów rzecznych.

\section{Bibliografia}

\section{Archiwalia}

\section{Archiwum Akademii Górniczo-Hutniczej}

Protokoły posiedzeń Ogólnego Zebrania Kolegium Profesorów Akademii Górniczej, sygn.: $17 / 2,17 / 3,17 / 4$.

Akta Osobowe K.F. Vetulaniego, sygn. 13/413.

\section{Archiwum Akt Nowych}

Ministerstwo Wyznań Religijnych i Oświecenia Publicznego, sygn. 6366.

\section{Archiwum Nauki PAU i PAN}

Polska Akademia Umiejętności, k. 5g.

Spuścizna Adama Vetulaniego, sygn.: 45, 131, 186, 240, 322.

Archiwum Obwodowe we Lwowie

Akta studenckie K.F. Vetulaniego, sygn. 27/5/2190A.

Akta wykładowcy K.F. Vetulaniego, sygn. 27/4/107.

Archiwum Polskiej Akademii Nauk, Oddział w Poznaniu

Spuścizna Tadeusza Vetulaniego, sygn. 104.

\section{Archiwum Uniwersytetu Jagiellońskiego}

Akta Osobowe K.F. Vetulaniego, sygn. WF II 121.

160 Ibidem, k. 26.

161 J. Piłatowicz, Politechnika Lwowska w dwudziestoleciu międzywojennym, „Kwartalnik Historii Nauki i Techniki” 36, 1991, nr 1, s. 25-70.

162 A. Śródka, Uczeni polscy XIX-XX stulecia, Warszawa 1998, t. 4, s. 423. 


\section{Centralne Archiwum Wojskowe}

Departament Techniczny Ministerstwa Spraw Wojskowych, sygn. I 300.41.151.

Kolekcje rękopisów, sygn. I 400.2105.

Kartoteki, sygn. MN 17.03.1932.

Oddział IV Zaopatrzenia i Komunikacji Ministerstwa Spaw Wojskowych, sygn. I 300.10.03.

\section{Instytut Pamięci Narodowej Oddział we Wrocławiu}

IPN Wr 587/162, K. Fiedor, Zbrodnie popełnione na profesorach lwowskich w lipcu $1941 \mathrm{r}$.

\section{Źródła publikowane}

II Państwowe Liceum i Gimnazjum im. K. Szajnochy we Lwowie (nr 560) (lata szkolne 1819/1820-1938/1939). Dokumenty przeszłości, oprac. J. Kowalczuk, Kraków 2008.

Historia szkolnictwa, oświaty $i$ wychowania na ziemiach Odtaczonych II RP - Kresach Potudniowo-Wschodnich, t. 11. Politechnika Lwowska, oprac. J. Kowalczuk, Kraków 2013, cz. 3.

Piórek J., Z protokołów Towarzystwa Matematycznego w Krakowie, „Matematyka. Społeczeństwo Nauczanie" 1989, nr 3, s. 4-10.

Siwik A., Artymiak R., Kwiek J., „Podejmując rozpoczęte dzieło...” Akademia Górnicza 1919-1939. Dokumenty, Kraków 2014.

Więsław W., Listy Wacława Sierpińskiego do Stanisława Ruziewicza, „Wiadomości Matematyczne" 40, 2004.

\section{Wspomnienia}

Albiński M., Wspomnienia o Banachu i Wilkoszu, „Wiadomości Matematyczne” 19, 1976.

Gołąb S., Z dziejów założenia Polskiego Towarzystwa Matematycznego, „Wiadomości Matematyczne" 4, 1961.

Relacja L. Szargułowej z 22 października 1971, [w:] Kaźń profesorów lwowskich - lipiec 1941. Studia oraz relacje i dokumenty, zeb. i oprac. Z. Albert, Wrocław 1989.

Romańska Z., Romański R.B., Z przeszłości kolejnictwa w Nowym Sączu (wspomnienia), „Rocznik Sądecki” 15/16, 1974-1977.

Rotkiewicz M., Mózg i błazen, Rozmowa z Jerzym Vetulanim, Wołowiec 2015.

\section{Opracowania}

Adam Vetulani 1901-1976 Materiaty z posiedzenia naukowego PAU w dniu 16 listopada 2001 r., red. R. Majkowska, Kraków 2005.

Aleksander T., Życie społeczne i przemiany kulturalne Nowego Sącza w latach 1870-1990, Kraków 1993.

Bagiński H., U podstaw organizacji Wojska Polskiego 1908-1914, Warszawa 1935.

Bonusiak W., Kto zabit profesorów lwowskich?, Rzeszów 1989.

Chmielewska M., Leksykon polskich pisarzy muzycznych XX wieku, Wołomin 2008.

Długosz J., Polska Akademia Nauk Technicznych w Warszawie (1920-1939). Zarys dziejów, skład osobowy, osiagnięcia, Poznań 2002.

Duda R., Lwowska szkoła matematyczna, Wrocław 2014.

Dzieje miasta Nowego Sącza, red. F. Kiryk, Z. Ruta, t. 3, Kraków 1996.

Wrocławskie Studia Wschodnie 24, 2020

(C) for this edition by CNS 
Dziurzyńska E., Adam Vetulani (1901-1976), [w:] Korespondencja Adama Vetulaniego z Miroslavem Bohackiem, oprac. E. Dziurzyńska, M. Sumova, Kraków 2017.

Jastrzębski J., Instytucja profesury zwyczajnej w polskim państwowym szkolnictwie akademickim w latach 1920-1939, Kraków 2018.

Juniewicz S., Budownictwo Wodne na Politechnice Lwowskiej i Wrocławskiej, Wrocław 1987.

Kraków muzyczny 1918-1939, red. M. Drobner, T. Przybylski, Kraków 1980.

Krawczak T., Odziemkowski J., Polskie pociagi pancerne 1918-1939, „Przegląd Wojskowo-Historyczny" 24, 1979, nr 4.

Księga pamiątkowa pierwszego polskiego zjazdu matematycznego Lwów, 7-10.09.1927, Kraków 1929.

Księga SIMP. Pót wieku działalności mechaników polskich w przemyśle, Warszawa 1963.

Kuczyński A., Wójcik Z., Kaźń profesorów lwowskich, „Wrocławskie Studia Wschodnie” 2015, nr 19.

Leśniak J., Nowa encyklopedia sądecka, Nowy Sącz 2017.

Łysakowski P., Mord na profesorach lwowskich — lipiec 1941 r., „Dzieje Najnowsze” 2012, nr 3.

Magnuski J., Pociag pancerny Śmiaty w trzech wojnach, Warszawa 1996.

Maligranda L., Prytuła J.G., Lwowscy uczeni wymienieni w przestuchaniach Banacha w 1944 r., „Wiadomości Matematyczne” 2013, nr 49 (1).

Marmon W., Vetulani Tadeusz, [w:] Słownik biograficzny historii Polski, t. 2. L-Ż, Wrocław-Kraków 2005.

Ostrówka A.J., Pociagi pancerne Wojska Polskiego 1918-1939, Toruń 2013.

Piłatowicz J., Politechnika Lwowska w dwudziestoleciu międzywojennym, „Kwartalnik Historii Nauki i Techniki” 36, 1991, nr 1.

Piłatowicz J., Ruch stowarzyszeniowy inżynierów i techników polskich do 1939 r., t. 2. Słownik polskich stowarzyszeń technicznych i naukowo-technicznych do 1939 r., Warszawa 2005.

Popławski Z., Dzieje Politechniki Lwowskiej 1844-1945, Wrocław 1992.

Popławski Z., Represje okupantów na Politechnice Lwowskiej, [w:] Lwów i lwowianie. Pamiętniki Wspomnienia Relacje, oprac. J. Kowalczuk, cz. 3, Kraków 2011.

Popławski Z., Wykaz pracowników naukowych Politechniki Lwowskiej w latach 1844-1945, Kraków 1994.

Przeniosło M., Matematycy polscy $w$ dwudziestoleciu międzywojennym. Studium historyczne, Kielce 2011.

Rakowski A., Kategorialna percepcja wysokości dźwięku w muzyce, Warszawa 1978.

Sanok. Dzieje miasta, red. F. Kiryk, Kraków 1995.

Schenk D., Noc morderców. Kaźń polskich profesorów we Lwowie i holokaust w Galicji Wschodniej, Kraków 2011.

Skarżyński T., Martyrologia, straty wojenne i okupacyjne środowiska Politechniki Lwowskiej (1918-1945), [w:] Politechnika Lwowska Macierz polskich politechnik, materiały z konferencji 25-26 września 1995, red. M. Sroczyński et al., t. 1, Wrocław 1995.

Skrzyński T., Aktywność Tadeusza Banachiewicza na posiedzeniach walnych $i$ w pracach Wydzialu Matematyczno-Przyrodniczego Polskiej Akademii Umiejętności w latach 1919 1952, „Studia Historyczne” 58, 2015, nr 3.

Słownik biograficzny matematyków polskich, red. S. Domaradzki, Z. Pawlikowska-Brożek, D. Węglowska, Tarnobrzeg 2003.

Stownik biograficzny polskiej stużby zagranicznej 1918-1945, oprac. K. Smolana, Warszawa 2007, t. 1. 
Sroczyński R., Politechnika Lwowska macierz polskich politechnik 1844-1994, [w:] Ksiegga jubileuszowa 25-lecia Wyktadów Historii Nauki i Techniki prof. dr hab. Ryszarda Sroczyńskiego, Wrocław 1997.

Syrwid R., „Ambasadorka Watykanu”, czyli Cecylii Vetulani potyczki z władza ludowa. Nieznany list do Komisji Kultury Wojewódzkiej Rady Narodowej w Olsztynie z 1955 roku, „Komunikaty Mazursko-Warmińskie” 2 (276), 2012.

Szewalski R., Politechnika Lwowska w latach wojny i okupacji (1939-1945), [w:] Lwowskie środowisko naukowe w latach 1939-1945, red. I. Stasiewicz-Jasiukowa, Warszawa 1993.

Śródka A., Uczeni polscy XIX-XX stulecia, t. 4, Warszawa 1998.

Tatarkiewicz K., Uwagi o historii dwóch wieków mechaniki w Polsce, [w:] Matematyka polska w stuleciu 1851-1950. Materiały z IX Ogólnopolskiej Szkoły Historii Matematyki. Międzyzdroje 5-9 czerwca 1995, red. S. Fudali, Szczecin 1995.

Vetulani K.F., O strugach cieczy, odbitka z „Czasopisma Technicznego”, Lwów 1933.

Vetulani K.F., Orzeczenie techniczne o użyteczności kamienia z Mogielnicy da celów komunikacyjno-budowlanych, Warszawa 1931.

Vetulani K.F., W sprawie wyboczenia, odbitka z „Czasopisma Technicznego”, Lwów 1930.

Walczak M., Ludzie nauki i nauczyciele podczas II wojny światowej. Księga strat osobowych, Warszawa 1995.

Węgierski J., Krawczyk J., Wydział Inżynierii, [w:] Politechnika Lwowska 1844-1945, red. J. Boberski et al., Wrocław 1993.

Wojtkiewicz-Rok W., Sylwetki uczonych polskich pomordowanych we Lwowie w lipcu 1941 r., [w:] Kaźń profesorów lwowskich — lipiec 1941. Studia oraz relacje i dokumenty, zeb. i oprac. Z. Albert, Wrocław 1989.

Z dziejów Akademii Górniczo-Hutniczej w Krakowie w latach 1919-1967, Kraków 1970.

Zając E., Vetulani Roman (1849-1908), pedagog, autor podręczników szkolnych, organizator pracy oświatowo-patriotycznej, [w:] Stownik biograficzny twórców oświaty i kultury XIX i XX wieku Polski potudniowo-wschodniej. Suplement, red. K. Szmyd, Rzeszów 2015, s. $140-141$.

Zakrzewski L., Pociagi pancerne z Warsztatów Głównych w Nowym Sączu, [w:] Kolejarze polscy dla niepodległej ojczyzny, Kraków 2018.

\section{Netografia}

Prof. dr inż., kpt. rez WP II RP Kazimierz Franciszek Vetulani, https://www.ogrodywspomnien. pl/index/showd/109898\#book (dostęp: 4.04.2019).

\section{Inne}

Czy wiesz kto to jest?, red. S. Łoza, Warszawa 1938.

Kryska-Karski T., Straty korpusu oficerskiego 1939-1945, Londyn 1996.

Księga adresowa miasta Krakowa i województwa krakowskiego 1932, Kraków 1932.

L'vìvs'ka politehnika v publikaciâh (1844-2013) bibliografičnij pokažčik, red. Ì. Bêlous, O. Šiški, L'vìv 2014.

Ranglisten des Kaiserlichen und Köninglichen Heeres 1918. Abgeschlossen mit Personalverordnungsblatt nr 40/18, Vien 1918.

Rocznik oficerski rezerw 1934, reprint, Warszawa-Londyn 2003. 
Wielka księga adresowa stot. król. miasta Krakowa, Kraków 1925.

Z życia i działalności Adama Vetualniego 1901-1976. Katalog wystawy, Kraków 2001.

Wrocławskie Studia Wschodnie 24, 2020

(C) for this edition by CNS 